\title{
Carrier Lifetime Controlling Defects Z(1/2) and RB1 in Standard and Chlorinated Chemistry Grown 4H-SiC
}

Ian Don Booker, Jawad Ul Hassan, Louise Lilja, Franziska Beyer, Robin Karhu, J. Peder Bergman, Orjan Danielsson, Olof Kordina, Einar Sveinbjörnsson and Erik Janzén

\section{Linköping University Post Print}

\section{Tweet}

N.B.: When citing this work, cite the original article.

Original Publication:

Ian Don Booker, Jawad Ul Hassan, Louise Lilja, Franziska Beyer, Robin Karhu, J. Peder Bergman, Orjan Danielsson, Olof Kordina, Einar Sveinbjörnsson and Erik Janzén, Carrier Lifetime Controlling Defects Z(1/2) and RB1 in Standard and Chlorinated Chemistry Grown 4H-SiC, 2014, Crystal Growth \& Design, (14), 8, 4104-4110.

http://dx.doi.org/10.1021/cg5007154

Copyright: American Chemical Society http://pubs.acs.org/

Postprint available at: Linköping University Electronic Press http://urn.kb.se/resolve?urn=urn:nbn:se:liu:diva-110278 


\section{Carrier lifetime controlling defects $\mathrm{Z}_{1 / 2}$ and $\mathrm{RB} 1$ in standard- and chlorinated chemistry grown $4 \mathrm{H}-\mathrm{SiC}$}

Ian D. Booker*, ${ }^{*}$, Jawad Ul Hassan ${ }^{1}$, Louise Lilja ${ }^{1}$, Franziska C. Beyer ${ }^{1, \dagger}$, Robin Karhu ${ }^{1}$, J. Peder Bergman $^{1}$, Örjan Danielsson ${ }^{1}$, Olof Kordina ${ }^{1}$, Einar Ö. Sveinbjörnsson ${ }^{1,2}$, Erik Janzén ${ }^{1}$

${ }^{1}$ Department of Physics, Chemistry and Biology (IFM), Semiconductor Materials Division, Linköping University, 58183 Linköping, Sweden

${ }^{2}$ Science Institute, University of Iceland, IS-107, Reykjavik, Iceland

†present address: Fakultät für Chemie und Physik, Institut für Angewandte Physik, Technische Bergakademie Freiberg, Leipziger Straße 23, 09596 Freiberg, Germany

ABSTRACT 4H-SiC epilayers grown by standard and chloride based chemistry were analyzed for their minority carrier lifetime and deep level recombination centers using time resolved photoluminescence (TRPL) and standard and $p^{+} / n$-junction deep level transient spectroscopy (DLTS). Next to the wellknown $Z_{1 / 2}$ deep level a second effective lifetime killer, RB1 is detected in chloride chemistry grown epilayers. The measured RB1 concentration appears to be a function of the iron-related Fel level concentration, which is introduced via the corrosion of reactor steel parts by the chlorinated chemistry. Reactor design and the temperature profile in the growth zone appear to enable the formation of RB1 in the presence of iron contamination under conditions otherwise optimal for growth of material with very low $\mathrm{Z}_{1 / 2}$ concentrations. Control of these corrosion issues allows the growth of material at a significantly higher growth rate than possible using standard chemistry and with high minority carrier lifetime based on $Z_{1 / 2}$ as the only bulk recombination center.

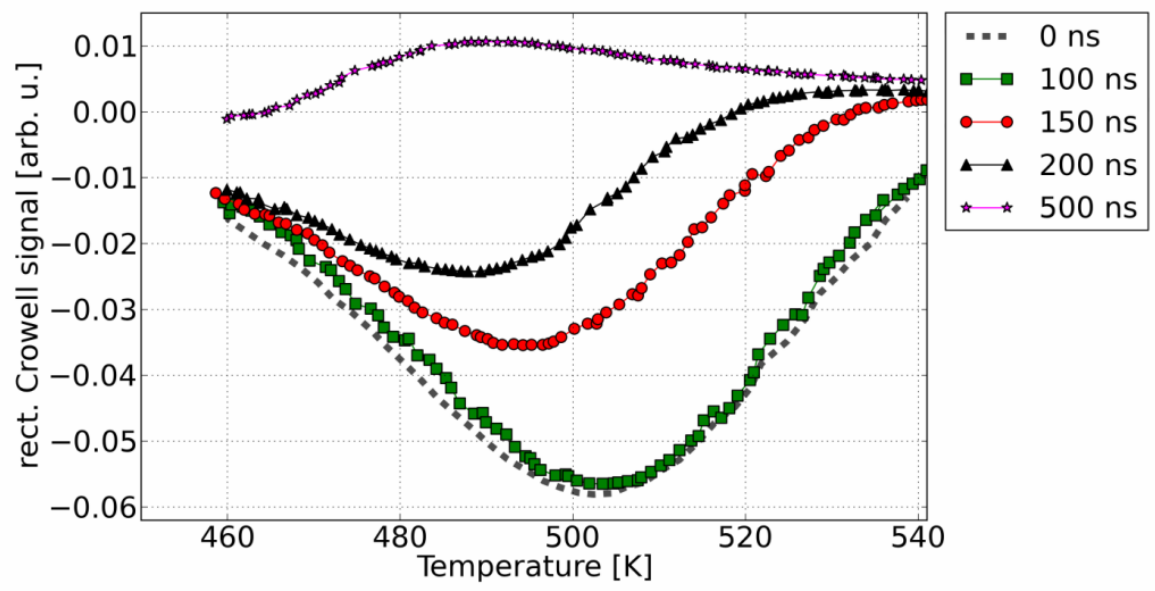

Figure. $p^{+} / n$-junction DLTS measurements of RB1 for different hole injection pulse lengths. DLTS parameters were: reverse bias $-2 \mathrm{~V}$; first electron saturation pulse $2 \mathrm{~V}, 10 \mathrm{~ms}$ duration; and second hole injection pulse $4 \mathrm{~V}$ of varying length given in the figure legend.

*Ian Don Booker

Department of Physics, Chemistry and Biology (IFM), Semiconductor Materials Division, Linköping University, 58183 Linköping, Sweden

Phone: +4613288936

Email: ianbo@ifm.liu.se 


\title{
Carrier lifetime controlling defects $\mathrm{Z}_{1 / 2}$ and $\mathrm{RB} 1$ in
}

\section{standard- and chlorinated chemistry grown $4 \mathrm{H}-\mathrm{SiC}$}

Ian D. Booker ${ }^{*}$, , Jawad Ul Hassan ${ }^{l}$, Louise Lilja ${ }^{l}$, Franziska C. Beyer ${ }^{1, \grave{ }}$, Robin Karhu ${ }^{l}$, J. Peder Bergman ${ }^{1}$, Örjan Danielsson ${ }^{l}$, Olof Kordina ${ }^{l}$, Einar Ö. Sveinbjörnsson ${ }^{1,2}$, Erik Janzén ${ }^{l}$

${ }^{1}$ Department of Physics, Chemistry and Biology (IFM), Semiconductor Materials Division, Linköping University, 58183 Linköping, Sweden

${ }^{2}$ Science Institute, University of Iceland, IS-107, Reykjavik, Iceland

†present address: Fakultät für Chemie und Physik, Institut für Angewandte Physik, Technische Bergakademie Freiberg, Leipziger Straße 23, 09596 Freiberg, Germany

KEYWORDS 4H-SiC, DLTS, TRPL, $\mathrm{Z}_{1 / 2}$, minority carrier lifetime, deep level, lifetime killer, chlorinated chemistry.

\begin{abstract}
4H-SiC epilayers grown by standard and chlorinated chemistry were analyzed for their minority carrier lifetime and deep level recombination centers using time resolved photoluminescence (TRPL) and standard deep level transient spectroscopy (DLTS). Next to the well-known $Z_{1 / 2}$ deep level a second effective lifetime killer, RB1 (activation energy $1.05 \mathrm{eV}$, electron capture cross section $2 \cdot 10^{-16} \mathrm{~cm}^{2}$, suggested hole capture cross section $(5 \pm 2) \cdot 10^{-15} \mathrm{~cm}^{2}$ ), is detected in chloride chemistry grown epilayers. Junction-DLTS and bulk recombination simulations are
\end{abstract}


used to confirm the lifetime killing properties of this level. The measured RB1 concentration appears to be a function of the iron-related Fel level concentration, which is unintentionally introduced via the corrosion of reactor steel parts by the chlorinated chemistry. Reactor design and the growth zone temperature profile are thought to enable the formation of RB1 in the presence of iron contamination under conditions otherwise optimal for growth of material with very low $Z_{1 / 2}$ concentrations. The $R B 1$ defect is either an intrinsic defect similar to $R_{1 / 2}$ or $E H 5$ or a complex involving iron. Control of these corrosion issues allows the growth of material at a high growth rate and with high minority carrier lifetime based on $Z_{1 / 2}$ as the only bulk recombination center.

\section{INTRODUCTION}

$4 \mathrm{H}-\mathrm{SiC}$ is an attractive material for high power, high frequency bipolar switching devices such as the bipolar junction transistor (BJT). To allow these power-devices to handle voltages in the $\mathrm{kV}$ range, thick low-doped blocking layers are required. Recently, for example a $21 \mathrm{kV}$ device using a $186 \mu \mathrm{m}$ thick $n$-type doped $\left(2.3 \cdot 10^{14} \mathrm{~cm}^{-3}\right)$ collector was demonstrated. ${ }^{1}$ For layers of this thickness chlorinated chemistry would offer the advantage of growth rates beyond $100 \mu \mathrm{m} / \mathrm{h}$ compared to standard chemistry, where growth rates are generally in the range $5-30 \mu \mathrm{m} / \mathrm{h}^{2}$ This would allow for significantly larger throughputs in manufacturing.

One central issue for bipolar devices is the carrier lifetime, which must be tailored to the specific device. Apart from extended structural defects, electrically active deep levels (simple point defects or clusters) may limit the carrier lifetime, specifically if they capture minority and majority carriers with similar efficiency and thus act as recombination centers. In as-grown $4 \mathrm{H}-\mathrm{SiC}$ epilayers, the main recombination center is the $\mathrm{Z}_{1 / 2}$ level, related to the double acceptor 
level $(2-\mid 0)$ of the simple carbon vacancy $\mathrm{V}_{\mathrm{C}}{ }^{3-5}$ In contrast to the case of $\mathrm{Si}$, where transition metals incorporated into the material during growth significantly degrade electrical properties such as the minority carrier lifetime, ${ }^{6,7}$ this topic has received limited attention in $4 \mathrm{H}-\mathrm{SiC}$ since these contaminants appear to be inefficient deep level recombination centers.

Previous work found that high-purity chloride chemistry grown epilayers include the same deep levels as layers grown by standard chemistry. ${ }^{8,9}$ In this study, we show that next to $Z_{1 / 2}$ a second lifetime limiting defect, RB1 can occur in chloride chemistry grown epilayers due to a self-contamination of the cell with iron caused by the chloride containing chemistry corroding steel reactor parts. The carrier lifetime in these epilayers is therefore controlled by $\mathrm{Z}_{1 / 2}$ and $\mathrm{RB} 1$, unless reactor design is optimized to avoid this.

\section{EXPERIMENTAL DETAILS}

A total of thirty-four (34) $4 \mathrm{H}-\mathrm{SiC}$ epilayers were grown on $\mathrm{Si}$-face, $8^{\circ}$ and $4^{\circ}$ off-cut $4 \mathrm{H}-\mathrm{SiC}$ substrates. Nitrogen doping provided $4 \cdot 10^{13}$ to $8 \cdot 10^{15} \mathrm{~cm}^{-3} n$-type conductivity and the epilayer thicknesses ranged from 25 to $50 \mu \mathrm{m}$. For growth, three different horizontal hot-wall MOCVD reactors with four cells were used. The first is a current generation Aixtron VP-508 double-cell reactor with gas-foil sample rotation where one cell is used for standard chemistry (referred to as S1) and the other for chlorinated chemistry (C1). Both inductively heated graphite reaction chambers are $\mathrm{TaC}$ coated. The second and third reactors are a modified prototype VP-508 Epigress reactor using standard chemistry (S2) and another modified prototype, this one using chlorinated chemistry $(\mathrm{C} 2) .{ }^{10,11}$ Both are without sample rotation and use SiC coated graphite reaction chambers. The growth temperatures for all reactors are measured with a pyrometer on different parts of the susceptor and not directly on the samples. 
The precursors for standard chemistry growth were ethylene $\left(\mathrm{C}_{2} \mathrm{H}_{4}\right)$ or propane $\left(\mathrm{C}_{3} \mathrm{H}_{8}\right)$ and silane $\left(\mathrm{SiH}_{4}\right)$. For chlorinated growth, different combinations of methyltrichlorosilane $\left(\mathrm{CH}_{3} \mathrm{SiCl}_{3}\right.$, MTS), trichlorosilane $\left(\mathrm{SiHCl}_{3}, \mathrm{TCS}\right)$ and hydrogen chloride $(\mathrm{HCl})$ together with silane were used. $^{12}$ Of these, MTS was previously shown to be the most efficient precursor for high growth rates. ${ }^{13,14}$ As carrier gas, Pd-purified $\mathrm{H}_{2}$ was used. Table 1 gives an overview over the growth conditions and the respective number of samples.

Schottky contacts for electrical characterization were made by thermally evaporating $\mathrm{Ni}$ $(100 \mathrm{~nm})$ which was annealed at $300{ }^{\circ} \mathrm{C}$ for 5 min before deep level transient spectroscopy (DLTS). Ag-paste applied to the backside of the $n+$ substrate gave the ohmic contact. For measurements on $p^{+} / n$-junction a $p^{+}$layer $\left(9 \cdot 10^{18} \mathrm{~cm}^{-3}\right.$ Al-doped $)$ of $\sim 700 \mathrm{~nm}$ thickness was

Table 1. Growth conditions of the analyzed samples from all 4 reactor cells.

\begin{tabular}{|c|c|c|c|c|}
\hline & Cell S1 & Cell S2 & Cell C1 & Cell C2 \\
\hline Number of samples & 7 & 9 & 7 & 11 \\
\hline Growth rate $[\mu \mathrm{m} / \mathrm{h}]$ & $6-30$ & $4-19$ & $22-106$ & $16-127$ \\
\hline $\mathrm{C} / \mathrm{Si}$ & $0.8-1.4$ & $1-1.2$ & $0.9-1.0$ & $0.8-1.1$ \\
\hline $\mathrm{Cl} / \mathrm{Si}$ & -- & -- & $3-5$ & $1-6$ \\
\hline $\mathrm{T}_{\text {growth }}\left[{ }^{\circ} \mathrm{C}\right]$ & $1630-1670$ & $1520-1670$ & $1600-1620$ & $1560-1600$ \\
\hline Pressure [mbar] & 100 & 100 & 100 & $100-200$ \\
\hline Precursors & $\begin{array}{l}\mathrm{C}_{2} \mathrm{H}_{4} \text { or } \mathrm{C}_{3} \mathrm{H}_{8} \\
+ \\
\mathrm{SiH}_{4}\end{array}$ & $\begin{array}{l}\mathrm{C}_{3} \mathrm{H}_{8} \\
+ \\
\mathrm{SiH}_{4}\end{array}$ & $\begin{array}{l}\mathrm{C}_{2} \mathrm{H}_{4} \\
+ \\
\mathrm{TCS}+\mathrm{HCl}\end{array}$ & $\begin{array}{l}\mathrm{C}_{2} \mathrm{H}_{4} \\
+ \\
\mathrm{MTS}+\mathrm{SiH}_{4} \text { or } \\
\mathrm{MTS}+\mathrm{HCl} \text { or } \\
\mathrm{MTS} \text { or } \mathrm{TCS} \text { or } \\
\mathrm{SiH}_{4}+\mathrm{HCl}\end{array}$ \\
\hline
\end{tabular}


re-grown onto the existing $n$-type epilayers at $1630^{\circ} \mathrm{C}$ and $100 \mathrm{mbar}$ pressure using standard $\left(\mathrm{C}_{3} \mathrm{H}_{8}+\mathrm{SiH}_{4}\right)$ chemistry. After growth, mesas were etched by inductively coupled plasma (ICP) down to the $n$-type epilayer to reduce surface leakage. Thermally evaporated Ni/Al (60/360 nm), annealed at $1000{ }^{\circ} \mathrm{C}$ for 2 min under $\mathrm{Ar}$ atmosphere served as Ohmic contacts to $p^{+}$, while Ohmic backside contacts to the $n^{+}$substrate were again made with Ag-paste.

Capacitance DLTS in the temperature range $77-650 \mathrm{~K}$ was measured on a self-built system with a detection limit $\sim 4$ orders of magnitude below the doping concentration. The transients were recorded for $700-3000 \mathrm{~ms}$, taking $60-200$ averages per temperature step. For standard majority carrier DLTS, a reverse bias of $-10 \mathrm{~V}$ and a $10 \mathrm{~V}$ filling pulse of $10 \mathrm{~ms}$ duration were used. For $p^{+} / n$-junction DLTS, a two-step pulse scheme was applied to achieve minority carrier injection: using a reverse bias of either -2 or $-6 \mathrm{~V}$, the first $10 \mathrm{~ms}$ filling pulse of $2 \mathrm{~V}$ or $6 \mathrm{~V}$ was immediately followed by a second forward biasing $4 \mathrm{~V}$ or $9 \mathrm{~V}$ pulse of varying length. The first pulse served to saturate the deep levels in the $n$-type material with electrons, while the second pulse injected minority holes into the $n$-layer from the $p^{+}$. Deep level parameters $\mathrm{E}_{\mathrm{a}}$ (apparent activation energy) and $\sigma_{\mathrm{n}}$ (apparent electron capture cross section) were obtained from fits to the full DLTS spectrum. A number of different medium- to high-resolution correlation functions (rectangular Crowell, GS4 and GS6) were used for the analysis. ${ }^{15,16}$

Room temperature time-resolved photoluminescence (TRPL) was measured using a $1.1 \mathrm{~ns}$ pulse length, $10 \mathrm{kHz}, 355 \mathrm{~nm}$ wavelength pulsed Nd:YAG laser and a Hamamatsu PMT. The near-band edge luminescence around $390 \mathrm{~nm}$ was selected out using $\pm 10 \mathrm{~nm}$ bandpass-filter. Samples were placed on a motorized xy-stage to map the areas of interest $\left(\sim 4 \mathrm{x} 4 \mathrm{~mm}^{2}\right)$ and the apparent minority carrier lifetime values $\left(\tau_{\text {meas }}\right)$ given are averages of at least 60 measurement points. 28.000 to 448.000 decays were averaged per point at a mid- $10^{16} \mathrm{ehp} / \mathrm{cm}^{3}$ injection level 
and the fitting was performed to the asymptotic part of the decay curve, at which the injected excess carrier density has decayed to a concentration below the doping density.

Secondary ion mass spectrometry (SIMS) measurement of the total Fe-, Mo- and Mnconcentrations was performed by EAG Labs (Sunnyvale, California) with detection limits of $(1-2) \cdot 10^{14} \mathrm{at} / \mathrm{cm}^{3}$ for $\mathrm{Fe}, 3 \cdot 10^{13} \mathrm{at} / \mathrm{cm}^{3}$ for Mo and $4 \cdot 10^{12} \mathrm{at} / \mathrm{cm}^{3}$ for $\mathrm{Mn}$.

For the wet-chemical testing of the reactor contaminating residue reagent grade potassium ferrocyanide $\left(\mathrm{K}_{4}\left[\mathrm{Fe}(\mathrm{CN})_{6}\right] \cdot 3 \mathrm{H}_{2} \mathrm{O}\right)$ and potassium ferricyanide $\left(\mathrm{K}_{3}\left[\mathrm{Fe}(\mathrm{CN})_{6}\right]\right)$ were used. ${ }^{17}$

Bulk recombination simulations were done by numerically solving the rate equations for the recombination of excess electrons $\delta \mathrm{n}(\mathrm{t})$ and holes $\delta \mathrm{p}(\mathrm{t})$ injected into $n$-type material:

$$
\begin{aligned}
& \frac{d \delta n}{d t}=-\sum_{i=1}^{w} R_{n, i} \\
& \frac{d \delta p}{d t}=-\sum_{i=1}^{w} R_{p, i}
\end{aligned}
$$

Here $R_{n}$ and $R_{p}$ are the net electron and hole capture rates for the $i=1,2, \ldots, w$ allowed transitions (for details see Klein, et al. ${ }^{3}$ ). The included recombination mechanisms were radiative, Auger and, most significantly, recombination via deep levels. As $Z_{1 / 2}$ is composed of two very closely spaced overlapping peaks and has a negative- $U$ nature, the rate-determining energy levels and capture cross sections from literature were used. ${ }^{3,18}$ The user defined parameters were the RB1 energy level $\left(\mathrm{E}_{\mathrm{a}}\right)$ and the electron and hole capture cross sections ( $\sigma_{\mathrm{n}}$ and $\sigma_{\mathrm{p}}$, respectively) as well as the $Z_{1 / 2}$ and $\mathrm{RB} 1$ deep level concentrations. For all parameters we used the values measured by DLTS, except for $\sigma_{\mathrm{p}}$, which could not be quantitatively measured and was the only fit parameter in the simulation.

Using the radiative recombination coefficient $\gamma$ and equations (1) and (2), a TRPL decay curve $\mathrm{I}_{\mathrm{PL}}(\mathrm{t})$ was then simulated, from which we extracted an instantaneous carrier lifetime $\tau_{\mathrm{PL}}$ : 


$$
\begin{gathered}
I_{P L}(t)=\gamma\left[n_{0}+\delta n(t)\right] \delta p(t) \\
\tau_{P L}=\frac{-I_{P L}(t)}{\left(\frac{d I_{P L}}{d t}\right)}
\end{gathered}
$$

This lifetime becomes the simulated minority carrier lifetime $\left(\tau_{\text {sim }}\right)$ in the limiting case when $\delta \mathrm{n}(\mathrm{t}), \delta \mathrm{p}(\mathrm{t})$ have decayed significantly below the net doping concentration $\mathrm{n}_{0}$. The value for $\sigma_{\mathrm{p}}$ could then be fitted by comparing the simulated $\left(\tau_{\text {sim }}\right)$ to the TRPL measured values $\left(\tau_{\text {meas }}\right)$. Drift/diffusion and surface recombination were not included into the simulation, which leads to deviations between $\tau_{\text {meas }}$ and $\tau_{\text {sim }}$ for high minority carrier lifetimes in the microsecond range. This is, however, unproblematic since we are interested mainly in samples with low lifetimes.

\section{RESULTS AND DISCUSSION}

Table 2 lists all major deep levels found in as-grown samples from the cells S1, S2, C2 and the self-contaminated cell $\mathrm{C} 1$. Note that $\mathrm{Z}_{1 / 2}$ was fitted as a single peak, not as two very closely spaced overlapping levels.

Two representative DLTS spectra, comparing a standard (S1) to self-contaminated chlorinated chemistry (C1) grown sample are given in Fig. 1. Four additional deep levels show up in cell C1, namely the previously reported $\mathrm{Fe} 1$ as well as $\mathrm{A}(1), \mathrm{A}(2)$ and RB1. ${ }^{19}$ Double-DLTS depth profiling on a low doped sample in the range of $5-17 \mu \mathrm{m}$ below the surface showed RB1 to be evenly distributed throughout the bulk. While Fe1 and RB1 densities vary strongly together over a wide range, $A(1)$ appears in lower densities similar to or lower than those of $Z_{1 / 2}$. $A(2)$ does not appear in every sample and only in very low densities. Some cell C2 grown samples also show 
Table 2. Parameters of all deep levels found in as-grown samples from the 4 growth cells. $Z_{1 / 2}$ and $\mathrm{EH}_{6 / 7}$ are fitted by as a single level defect for simplicity.

\begin{tabular}{|l|l|l|l|l|}
\hline Identification & $\mathrm{E}_{\mathrm{a}}[\mathrm{eV}]$ & $\sigma_{\mathrm{n}}\left[\mathrm{cm}^{2}\right]$ & $\sigma_{\mathrm{p}}\left[\mathrm{cm}^{2}\right]$ & Found in cells \\
\hline Ti(k) & 0.16 & $5.0 \cdot 10^{-15}$ & & $\mathrm{~S} 1, \mathrm{~S} 2, \mathrm{C} 1, \mathrm{C} 2$ \\
\hline $\mathrm{Fe} 1$ & 0.39 & $1.2 \cdot 10^{-15}$ & & $\mathrm{C} 1$ \\
\hline $\mathrm{Z}_{1 / 2}$ & 0.69 & $8.5 \cdot 10^{-15}$ & & $\mathrm{~S} 1, \mathrm{~S} 2, \mathrm{C} 1, \mathrm{C} 2$ \\
\hline $\mathrm{A}(1)$ & 0.71 & $7.0 \cdot 10^{-16}$ & & $\mathrm{C} 1$ \\
\hline $\mathrm{A}(2)$ & 0.90 & $6.0 \cdot 10^{-16}$ & & $\mathrm{C} 1$ \\
\hline $\mathrm{RB} 1$ & 1.05 & $2.0 \cdot 10^{-16}$ & proposed $\sim(5 \pm 2) \cdot 10^{-15}$ & $\mathrm{C} 1$ \\
\hline $\mathrm{EH}_{6 / 7}$ & 1.48 & $1.0 \cdot 10^{-14}$ & & $\mathrm{~S} 1, \mathrm{~S} 2, \mathrm{C} 1, \mathrm{C} 2$ \\
\hline
\end{tabular}

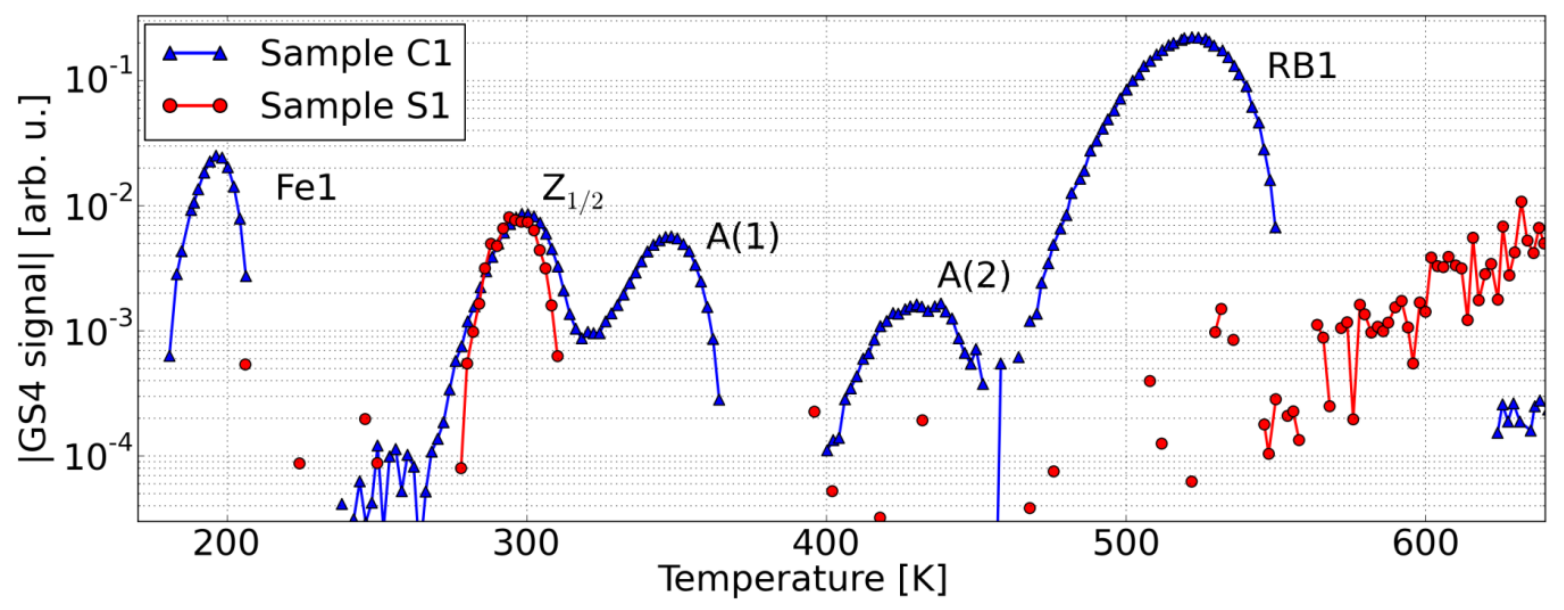

Figure 1. DLTS spectra of samples grown in cells C1 (blue triangles) or S1 (red circles),

showing deep levels $\mathrm{Fe} 1, \mathrm{Z}_{1 / 2}, \mathrm{~A}(1), \mathrm{A}(2)$ and $\mathrm{RB} 1$. The spectrum is plotted in absolute values and log-scaled for better comparability.

several additional very small peaks $\left(<5 \cdot 10^{10} \mathrm{~cm}^{-3}\right.$ concentration) at lower temperature. Of these levels, we will concentrate on $Z_{1 / 2}, \mathrm{Fe} 1$ and $\mathrm{RB} 1$ in the analysis. 
We performed DLTS on $p^{+} / n$-junctions to determine which of these levels function as recombination centers and propose an approximate hole capture cross section for RB1. The deep level concentrations of $\mathrm{Fe} 1, \mathrm{~A}(1)$ and $\mathrm{RB} 1$ found in the re-grown $p^{+} / n$-junctions $\left(\mathrm{T}_{\text {growth }} 1610{ }^{\circ} \mathrm{C}\right.$, $\mathrm{T}_{\text {re-growth }} 1630^{\circ} \mathrm{C}$ ) decreased only slightly relative to concentrations in the as-grown Schottky diodes, while the $\mathrm{Z}_{1 / 2}$ concentration increased by a factor 2.5 .

The filling pulse schemes are given together with the measurements in Fig. 2 and Fig. 3. After the first filling pulse to saturate the $\mathrm{Fe} 1, \mathrm{Z}_{1 / 2}$ and $\mathrm{RB} 1$ deep levels in the $n$-type region with electrons, the second pulse drives the diode into forward bias, injecting holes into the $n$-type region (of which some are captured by the deep levels) but also creating a counter-stream of electrons from the $n$ - into the $p^{+}$-type region. Varying the length of this second pulse allows us to observe the non-steady state minority capture behavior of the deep levels, since the amplitude of the DLTS signal now depends on the ratio of the electron and the hole capture cross sections. The steady-state electron concentration on the deep level under hole and electron injection is given $b^{20}$

$$
\begin{gathered}
n_{t}(\infty)=\frac{c_{n}}{c_{n}+c_{p}} N_{t} \\
c_{n, p}=\sigma_{n, p}\left\langle v_{n, p}\right\rangle c
\end{gathered}
$$

with $c_{n}$ and $c_{p}$ being the electron and hole capture rates, $N_{t}$ the total trap concentration, $\sigma_{n, p}$ the capture cross sections, thermal velocities $\left\langle\mathrm{v}_{\mathrm{n}, \mathrm{p}}\right\rangle$ and $\mathrm{c}$ the electron or hole concentration available for capture. If $c_{p}$ is small, no change in signal amplitude will be detectable. On the other hand, in case of increasing $c_{p} \geq c_{n}$, the signal amplitude will decrease more and more until it can be made to nearly vanish for $c_{p}>>c_{n}$. Due to a number of uncertainties specifically for the determination of the injected hole density, we present qualitative results from these measurements without attempting to calculate $\sigma_{\mathrm{p}}$. 
In Fig. 2, the spectra of $Z_{1 / 2}$ and Fe1 under different forward bias pulse lengths in a sample from cell $\mathrm{C} 1$ are shown. For the known recombination center $Z_{1 / 2}$, the peak amplitude is strongly dependent on the forward pulse duration, indicating $c_{p}>>c_{n}$. This is as expected, since the hole capture cross section was shown to be significantly larger than the electron capture cross section (these are $\sigma_{\mathrm{n} 1,2} \approx 1 \cdot 10^{-16} \mathrm{~cm}^{2},(2-4) \cdot 10^{-15} \mathrm{~cm}^{2}$ at $290 \mathrm{~K}$ and $\sigma_{\mathrm{p} 1,2} \approx 3.5 \cdot 10^{-14} \mathrm{~cm}^{2},(1-2) \cdot 10^{-14} \mathrm{~cm}^{2}$ for $\mathrm{Z}_{1}$ and $\left.\mathrm{Z}_{2}\right) \cdot{ }^{3,18} \mathrm{Fe} 1$ is only influenced minimally, indicating the opposite case with $\mathrm{c}_{\mathrm{p}}<<\mathrm{c}_{\mathrm{n}}$. $\mathrm{A}(1)$ and $\mathrm{A}(2)$ were not present in significant concentrations in the tested $p^{+} / n$-junctions and no conclusions can be drawn on these levels. In cases when their concentrations are above the detection limit, these are always lower than the $Z_{1 / 2}$ concentration; their influence on the carrier lifetime is therefore thought to be negligible.

In Fig. 3, the RB1 deep level shows behavior similar to that of $Z_{1 / 2}$ for varying forward pulse length. The peak height is strongly reduced with increasing forward bias pulse duration, clearly

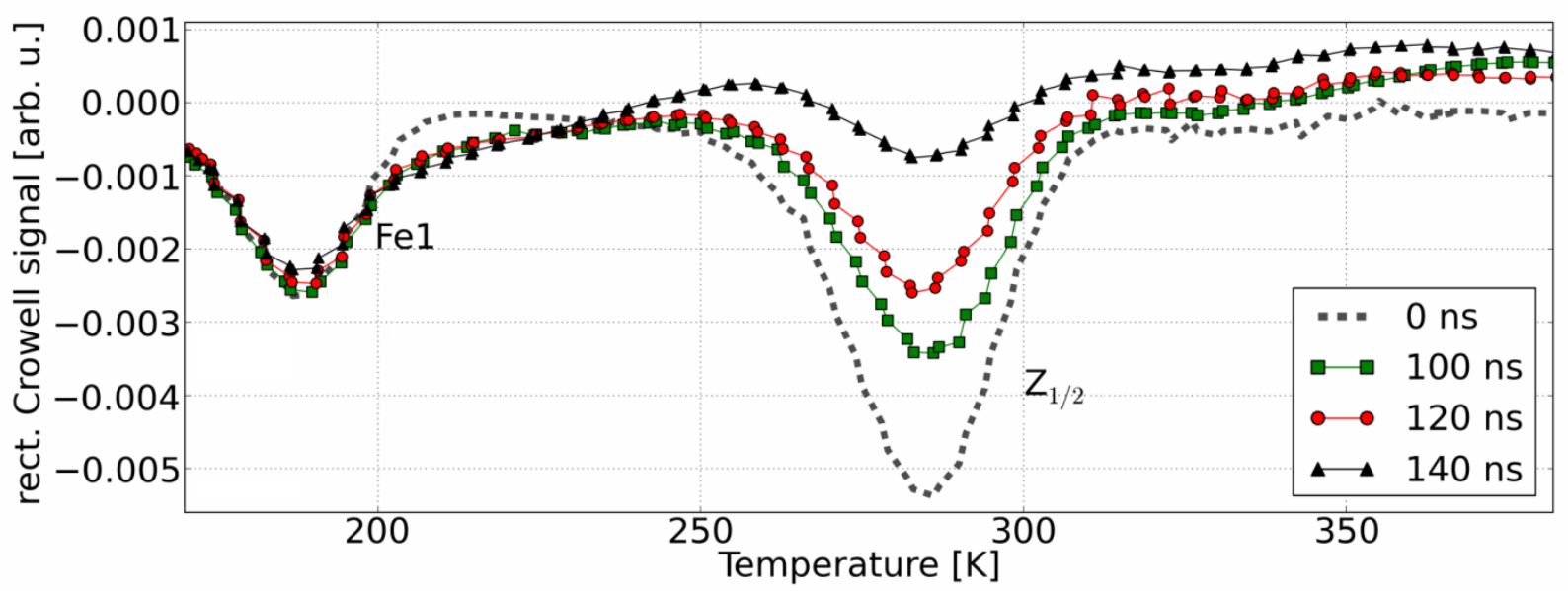

Figure 2. $p^{+} / n$-junction DLTS measurements on $\mathrm{Fe} 1$ and $\mathrm{Z}_{1 / 2}$ for different hole injection pulse lengths. DLTS parameters were: reverse bias $-6 \mathrm{~V}$; first electron saturation pulse $6 \mathrm{~V}, 10 \mathrm{~ms}$ duration; and second hole injection pulse $9 \mathrm{~V}$ of varying length given in the figure legend. 
indicating that RB1 has capture rates $c_{p}>>c_{n}$ and an apparent hole capture cross section $\sigma_{p}$ larger than its electron capture cross section $\left(\sigma_{\mathrm{n}}=2 \cdot 10^{-16} \mathrm{~cm}^{2}\right)$. Based on the extracted $\mathrm{E}_{\mathrm{a}}, \sigma_{\mathrm{n}}$ and the additional minority carrier lifetime simulations in the next sub-section 3.1 , we estimate $\sigma_{\mathrm{p}} \approx(5 \pm 2) \cdot 10^{-15} \mathrm{~cm}^{-2}$. The large peak position shift over temperature of RB1 compared to $\mathrm{Z}_{1 / 2}$ can be explained in two ways - either RB1 is composed of two levels with vastly different hole capture cross sections, or the minority injection efficiency into the $n$-type layer increases strongly over the $80 \mathrm{~K}$ measurement range.

3.1 Minority Carrier Lifetime and Recombination Centers. The measured minority carrier lifetime $\tau_{\text {meas }}$ versus $Z_{1 / 2}$ concentration in cells $\mathrm{S} 1, \mathrm{~S} 2$ and $\mathrm{C} 2$ is given in Fig. 4 (top). Using these concentrations, the plot in Fig. 4 (bottom) was created showing $\tau_{\text {sim }}$ versus $\tau_{\text {meas }}$. Deviation from the 1:1 line, where $\tau_{\text {meas }}=\tau_{\text {sim }}$ is caused mainly by two factors - the first is the combination of

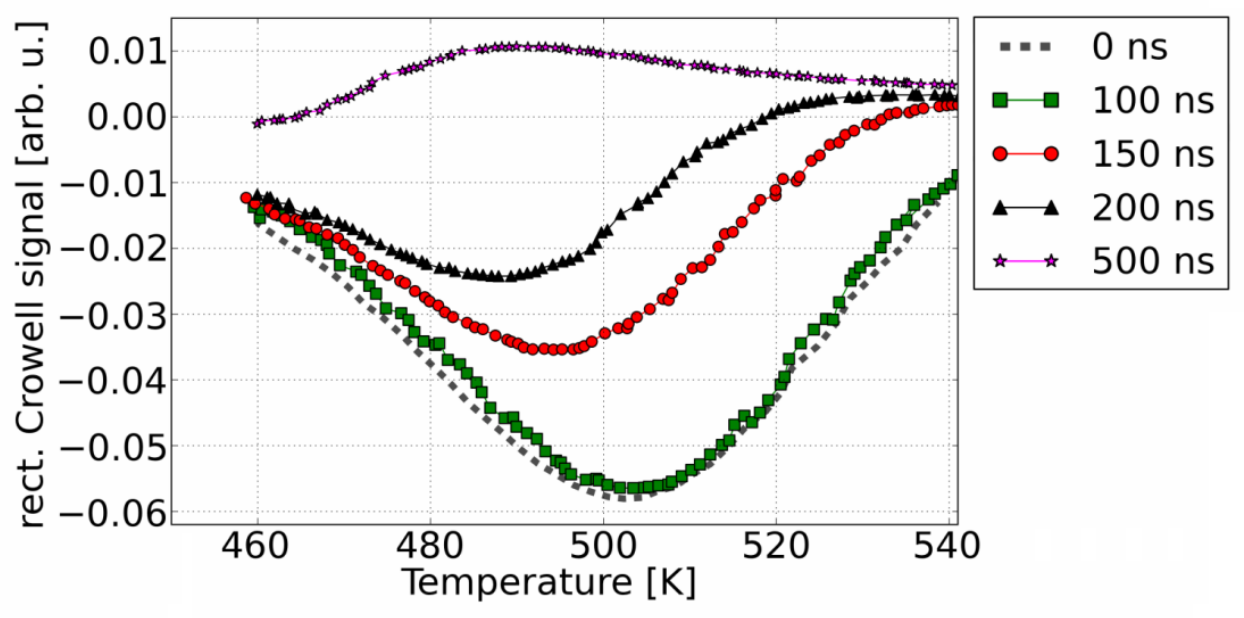

Figure 3. $p^{+} / n$-junction DLTS measurements of RB1 for different hole injection pulse lengths. DLTS parameters were: reverse bias $-2 \mathrm{~V}$; first electron saturation pulse $2 \mathrm{~V}, 10$ ms duration; and second hole injection pulse $4 \mathrm{~V}$ of varying length given in the figure legend. 
measurement uncertainties of the doping concentration (CV), deep level concentration (DLTS) and minority carrier lifetime (TRPL). The second factor is the lack of drift/diffusion and surface recombination in the simulation, which would reduce the effective simulated lifetime up to several times for high lifetime samples. ${ }^{21}$ None of these factors however would change the shown trend for samples from cells S1, S2 and C2.

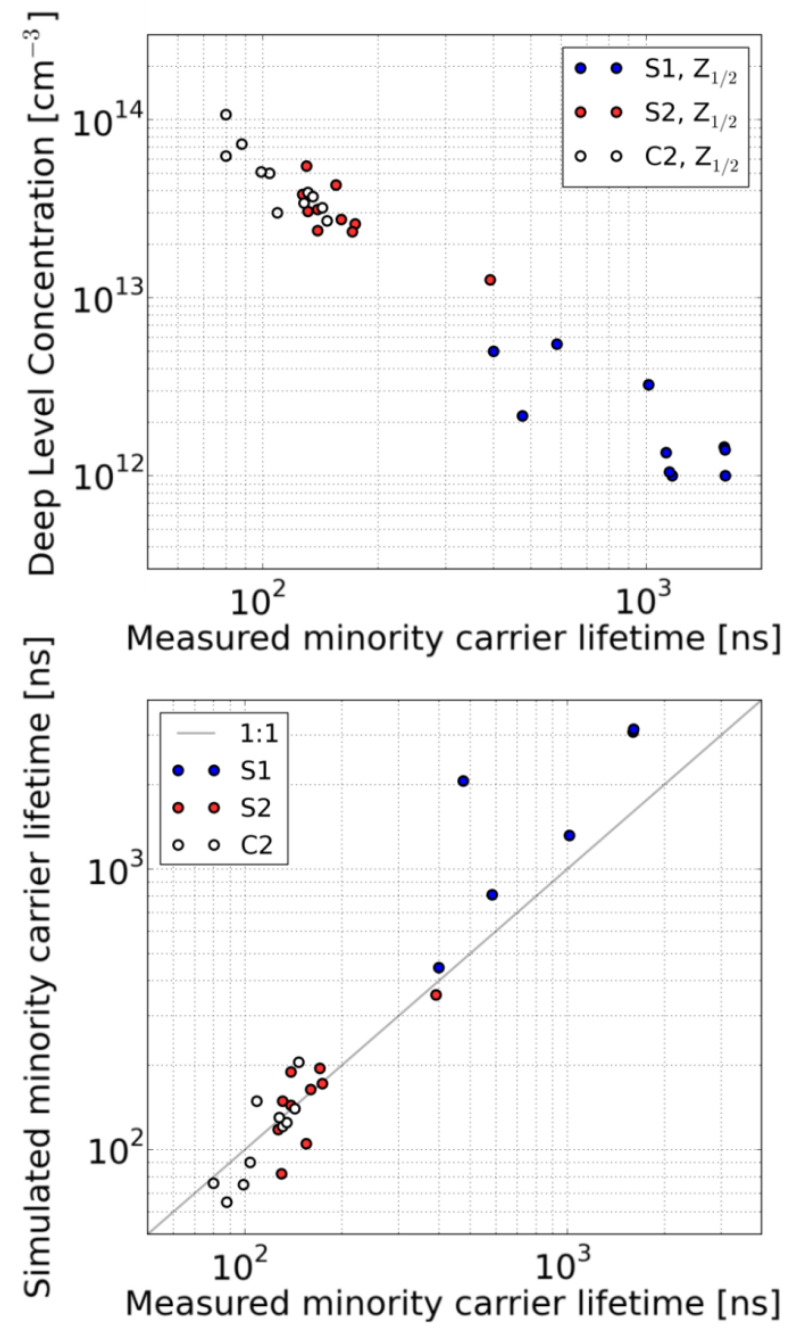

Figure 4. Top: $Z_{1 / 2}$ concentration versus TRPL measured minority carrier lifetime in samples from cells S1, S2 and C2. Bottom: Simulated versus measured bulk minority carrier lifetime using $Z_{1 / 2}$ in the detected concentrations as the only deep level recombination center. 
In cell $\mathrm{C} 1, \mathrm{Z}_{1 / 2}$ is no longer the only lifetime limiting defect, as can be seen from the plot of $\tau_{\text {meas }}$ versus $Z_{1 / 2}$ and RB1 concentrations in Fig. 5 (top) and from the plot of simulated versus measured lifetime in Fig. 5 (bottom). While the $Z_{1 / 2}$ concentration remains rather constant over
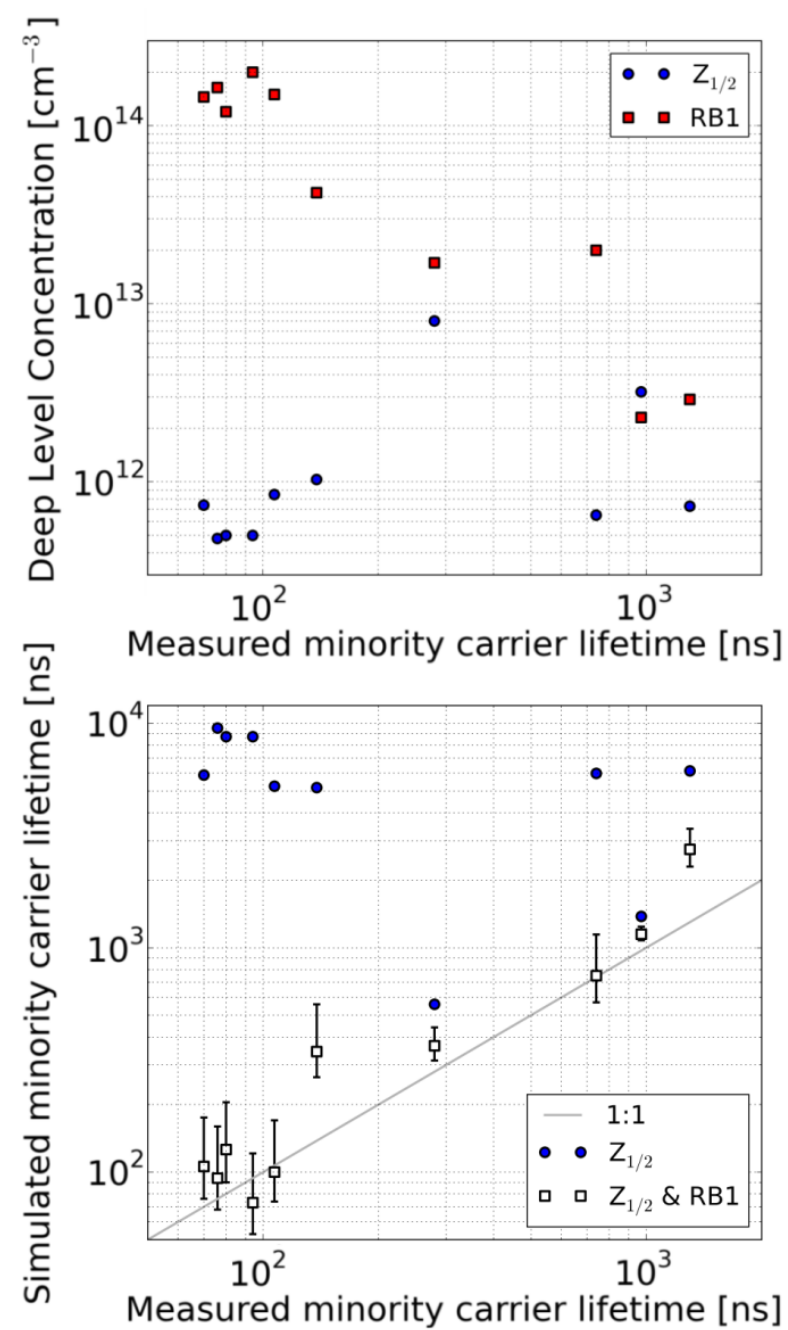

Figure 5. Top: $Z_{1 / 2}$ and RB1 deep level concentration versus TRPL measured minority carrier lifetime in samples from cell C1. Bottom: Simulated versus measured minority carrier lifetime using as deep level recombination centers only $Z_{1 / 2}$ (blue circles) or $Z_{1 / 2}$ and $R B 1$ (white squares). To approximately match $\tau_{\text {meas }}$ to $\tau_{\text {sim, }}$, we use a hole capture cross section of $(5 \pm 2) \cdot 10^{-15} \mathrm{~cm}^{2}$. 
all samples and their measured lifetimes (and slightly below that of highest lifetime samples grown in cell S1), RB1 appears in large concentrations with a trend anti-proportional to $\tau_{\text {meas }}$ and is the dominant recombination center in low-lifetime samples.

3.2 RB1 Formation. To study possible causes and origins of the new lifetime killing level, the concentrations of RB1 versus Fe1 in cell $\mathrm{C} 1$ are plotted in Fig 6. A clear sub-linear trend between the concentrations of both levels is visible. SIMS measurement of the total iron concentration was performed on one sample (Table 3) and the density of electrically active Fe1 levels is determined to be $3.9 \%$ of the total iron concentration. The total iron concentration thus is about two times larger than the RB1 concentration in this sample. The connection between Fe1, RB1 and the use of chlorinated chemistry can also be seen in the plot of deep level concentrations over growth rate of cell $\mathrm{C} 1$ in Fig. 7. To increase the growth rate, the chlorine to silicon ratio in the gas phase and the total flow of chlorinated precursors was increased. This greater abundance of chlorine produces faster corrosion of any exposed steel reactor parts and subsequent release of iron into the growth atmosphere.

The demonstrated link between Fe1, RB1 and chlorinated chemistry differs from the findings of Beyer, et al. ${ }^{19}$, who presented samples grown in cell $\mathrm{C} 2$ which were intentionally doped by Fe-flakes on the substrate but found no RB1 defect, despite using chlorinated chemistry with a growth rate of $100 \mu \mathrm{m} / \mathrm{h}$ and having similarly high Fel concentrations of $7.6 \cdot 10^{12} \mathrm{~cm}^{-3}$ and a total Fe concentration of $6.5 \cdot 10^{14} \mathrm{~cm}^{-3}$.

The lack of RB1 in the intentionally contaminated sample from $\mathrm{C} 2$ is thought to originate from differences in cell and susceptor design (sample rotation in $\mathrm{C} 1$ and $\mathrm{S} 1$ versus no rotation in $\mathrm{C} 2$ and $\mathrm{S} 2$ ) and susceptor coating ( $\mathrm{TaC}$ in cell $\mathrm{C} 1$ versus $\mathrm{SiC}$ in cell $\mathrm{C} 2$ ) which influence the temperature of the sample and the temperature gradient above the sample surface. While in C2 
the sample is placed directly onto the inductively heated $\mathrm{SiC}$ coated graphite susceptor, in $\mathrm{C} 1$ the sample sits on a smaller TaC coated graphite satellite rotating on a gas foil. The sample/satellite

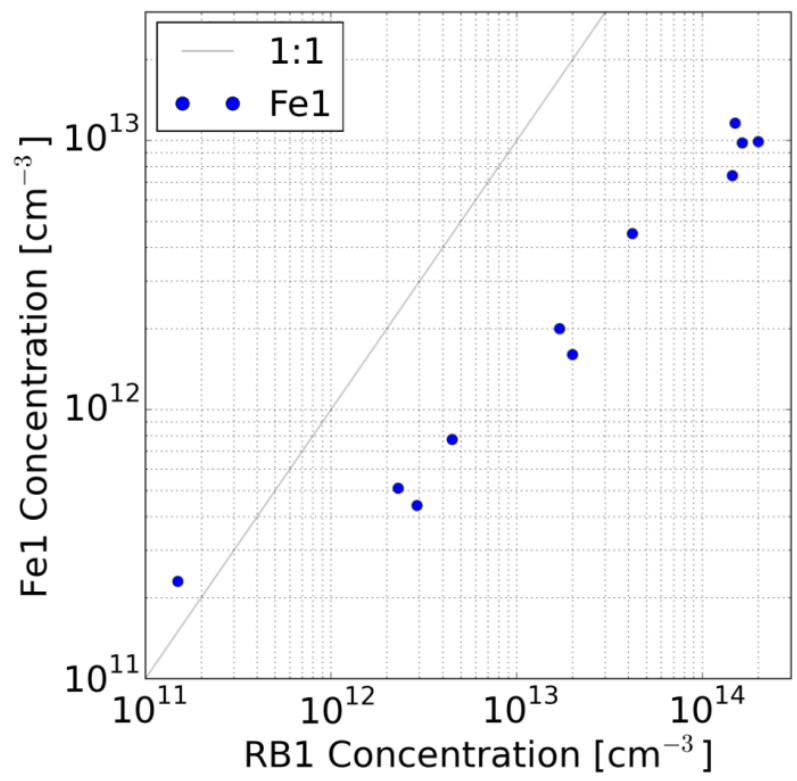

Figure 6. Fe1 concentration versus RB1 concentration in samples grown in cell $\mathrm{C} 1$.

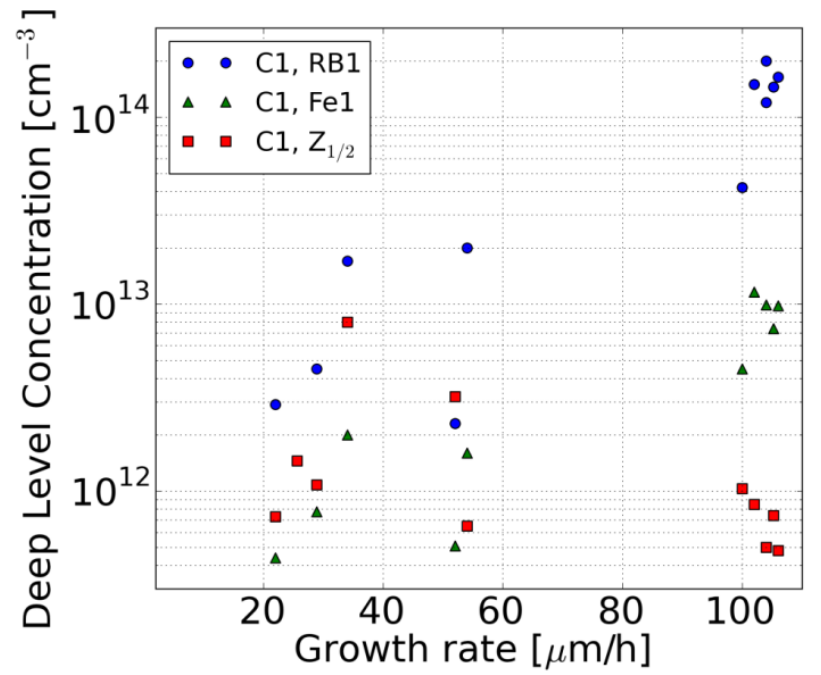

Figure 7. Fe1, RB1 and $Z_{1 / 2}$ deep level concentration over growth rate of samples grown in cell $\mathrm{C} 1$. Notice the low $\mathrm{Z}_{1 / 2}$ concentration in samples grown with more than $100 \mu \mathrm{m} / \mathrm{h}$ growth rate. 
temperature in this cell was found to be lower than the temperature of the surrounding susceptor by approximately $70{ }^{\circ} \mathrm{C}$, while in the non-rotating cell $\mathrm{C} 2$ (and the similarly built S2) the temperatures were almost equal.

The temperature difference will have a significant influence on the growth kinetics at the sample surface. A lower temperature generally reduces the reaction rates, and the reduction is larger for reactions with high activation energies, which means the rate limiting reactions may be altered when the temperature changes. Further, diffusion rates of the precursor species will be affected by the change in temperature and temperature gradients. The sum of these differences may have an impact on the $\mathrm{C} / \mathrm{Si}$ ratio at the sample surface and is reflected in the $\mathrm{Z}_{1 / 2}\left(\mathrm{~V}_{\mathrm{C}}\right)$ concentrations of as-grown samples, which are more than one order of magnitude lower in samples grown in cell $\mathrm{C} 1$ (and S1) compared to samples from cell C2 (and S2).

Annealing of cell $\mathrm{C} 1$ samples at a temperature close to the susceptor temperature of $1620{ }^{\circ} \mathrm{C}$ for 20 min corroborates this view that surface kinetics plays a major role in producing low- $Z_{1 / 2}$ samples in this cell. After annealing, the measured RB1 concentration decreased 2-3 times while the $Z_{1 / 2}$ concentration increased 7-16 times (see Table 4) in the probed top $2.5 \mu \mathrm{m}$ of the material. This increase in $Z_{1 / 2}$ concentration is significantly larger than the expected factor 3 increase based on a thermodynamic equilibrium $\mathrm{V}_{\mathrm{C}}$ density calculation using published experimental and calculated formation energies for $\mathrm{V}_{\mathrm{C}}$ in $n$-type doped samples. ${ }^{22,23}$ Therefore, we speculate that the cell $\mathrm{C} 1$ conditions and growth kinetics which are favorable for production 
Table 3. Fe1, $\mathrm{Z}_{1 / 2}$ and RB1 as determined by DLTS and total Fe concentration determined by SIMS for a sample grown in $\mathrm{C} 1$.

\begin{tabular}{|l|l|l|l|}
\hline Fe1 DLTS $\left[\mathrm{cm}^{-3}\right]$ & Fe SIMS $\left[\mathrm{cm}^{-3}\right]$ & $Z_{1 / 2}\left[\mathrm{~cm}^{-3}\right]$ & $\mathrm{RB} 1\left[\mathrm{~cm}^{-3}\right]$ \\
\hline $1.16 \cdot 10^{13}$ & $3 \cdot 10^{14}$ & $8.5 \cdot 10^{11}$ & $1.5 \cdot 10^{14}$ \\
\hline
\end{tabular}

of samples with a low concentration of the $Z_{1 / 2}$ lifetime killer defect are also responsible for the appearance of the iron contamination related RB1 level, which shows no correlation with $\mathrm{Z}_{1 / 2}$ in as-grown samples (see Fig. 5).

A literature survey of as-grown, irradiation or implantation induced defects was performed to compare the RB1 deep level parameters and its temperature stability to known intrinsic or extrinsic defects. Kotamraju, et al. ${ }^{24}$ detected a deep level at a similar position to RB1 using chlorinated carbon precursors in a cell contaminated with Fe and $\mathrm{V}$ at a low growth temperature of $1300^{\circ} \mathrm{C}$. A level identified as RD1/2 was found in another study in $4 \mathrm{H}-\mathrm{SiC}$ samples grown at $1500{ }^{\circ} \mathrm{C}$ in a cold-wall MOCVD reactor. ${ }^{25}$

Several more levels were detected after implantation or irradiation with different species and have parameters very close to RB1 but were found to anneal out at temperatures below $1500{ }^{\circ} \mathrm{C},{ }^{26,27,28}$ except in the study by Reshanov, et al. ${ }^{29}$. Table 5 lists the DLTS deep level parameters and annealing or growth temperatures for all of these levels. Because of the spread in deep level parameters and uncertainty in the annealing temperature, we cannot unambiguously identify RB1 as any one of these levels. We therefore suggest that RB1 may be an intrinsic deep level created by the incorporation and diffusion of iron or a complex involving iron. 
Table 4. Fe1, $Z_{1 / 2}$ and RB1 concentrations as determined by DLTS in a representative as-grown and annealed $\mathrm{C} 1$ sample and the value range of 11 as-grown samples from $\mathrm{C} 2$.

\begin{tabular}{|l|l|l|l|l|}
\hline Reactor (sample condition) & $\mathrm{T}_{\text {growth/anneal }}$ & $\mathrm{Fe} 1\left[\mathrm{~cm}^{-3}\right]$ & $\mathrm{Z}_{1 / 2}\left[\mathrm{~cm}^{-3}\right]$ & $\mathrm{RB} 1\left[\mathrm{~cm}^{-3}\right]$ \\
\hline C1 sample (as grown) & 1610 & $7.4 \cdot 10^{12}$ & $7.4 \cdot 10^{11}$ & $1.45 \cdot 10^{14}$ \\
\hline C1 sample (annealed 20 min) & 1620 & $6.7 \cdot 10^{12}$ & $8.2 \cdot 10^{12}$ & $3.76 \cdot 10^{13}$ \\
\hline C2 samples range (as grown) & $1560-1600$ & & $(3-10) \cdot 10^{13}$ & \\
\hline
\end{tabular}

Table 5. DLTS deep level parameters from literature and RB1 parameters for comparison.

\begin{tabular}{|c|c|c|c|c|c|}
\hline Deep level & Ref & $\mathrm{Ea}[\mathrm{eV}]$ & $\sigma_{\mathrm{n}}\left[\mathrm{cm}^{2}\right]$ & Sample preparation & $\begin{array}{l}\mathrm{T}_{\text {anneal/growth }} \\
{\left[{ }^{\circ} \mathrm{C}\right]}\end{array}$ \\
\hline (4) & 25 & 1.008 & $8 \cdot 10^{-17}$ & As-grown & 1300 \\
\hline $\mathrm{RD}_{1}$ & 26 & $0.9-0.97$ & $8 \cdot 10^{-15}-6 \cdot 10^{-14}$ & $\mathrm{Ti}^{+}$or $\mathrm{V}^{+}$implanted & $>1400$ \\
\hline $\mathrm{RD}_{2}$ & 26 & $0.92-1.01$ & $5 \cdot 10^{-16}-3 \cdot 10^{-15}$ & $\mathrm{Ti}^{+}$or $\mathrm{V}^{+}$implanted & $>1400$ \\
\hline $\mathrm{RD}_{1 / 2}$ & 26 & $0.89-0.97$ & $7 \cdot 10^{-16}-5 \cdot 10^{-15}$ & $\mathrm{He}^{+}$implanted & $>1400$ \\
\hline $\mathrm{RD}_{3}$ & 26 & $0.98-1.08$ & $5 \cdot 10^{-17}-3 \cdot 10^{-16}$ & $\mathrm{He}^{+}$implanted & $1000-1400$ \\
\hline EH5 & 27 & 1.15 & $3.5 \cdot 10^{-15}-1 \cdot 10^{-16}$ & $\mathrm{e}^{-}$irradiated & $>750$ \\
\hline $\mathrm{RD}_{1 / 2}$ & 28 & 0.96 & $5 \cdot 10^{-15}$ & Proton irradiated & 1500 \\
\hline $\mathrm{RD}_{3}$ & 28 & 1.0 & $1 \cdot 10^{-16}$ & Proton irradiated & 1500 \\
\hline $\mathrm{RD}_{1 / 2}$ & 27 & 1.01 & $8.4 \cdot 10^{-16}$ & As-grown & 1500 \\
\hline \multirow[t]{2}{*}{ EH5(?) } & 29 & 1.03 & $5 \cdot 10^{-15}$ & $\mathrm{e}^{-}$irradiated & $>1700$ \\
\hline & 29 & 1.01 & $8 \cdot 10^{-16}$ & $\mathrm{e}^{-}$irradiated & $>1700$ \\
\hline RB1 & & 1.05 & $2 \cdot 10^{-16}$ & As grown & 1600 \\
\hline
\end{tabular}


3.3 Iron Contamination Sources. The source of the iron contamination in the reactor was traced using potassium ferrocyanide and potassium ferricyanide to wet-chemically test deposition and crystallized/condensed residue from the quartz tube, steel flange, steel susceptor loading fork and susceptor. Large amounts of $\mathrm{Fe}^{3+}$ and $\mathrm{Fe}^{2+}$ ions were detected on the flange and the loading fork of cell $\mathrm{C} 1$ but not on steel parts from cell S1. Small amounts were found in the quartz tube in cell $\mathrm{C} 1$. We conclude that steel scraped off of the loading fork or from another corroding upstream part forms iron chloride during the temperature ramp-up and subsequent growth, which contaminates the sample area and then condenses further downstream near the flange and cell outlet. Other alloying elements of the steel (Mn, Mo, Cr) can be excluded as a direct source of RB1, as their concentrations in the tested sample are below the detection limit of either SIMS $\left(4 \cdot 10^{12} \mathrm{~cm}^{-3}\right.$ for Mn and $3 \cdot 10^{13} \mathrm{~cm}^{-3}$ for Mo) or DLTS $\left(10^{11} \mathrm{~cm}^{-3}\right.$ range Cr) and thus significantly lower than the samples RB1 concentration $\left(2.1 \cdot 10^{14} \mathrm{~cm}^{-3}\right)$.

\section{CONCLUSIONS}

TRPL and DLTS were used to analyze the minority carrier lifetime and deep level densities in samples grown in two standard and two chlorinated chemistry MOCVD cells. The carrier lifetime in three cells (S1, S2 and C2) was clearly controlled by recombination via the $\mathrm{Z}_{1 / 2}$ deep level. A second lifetime killing deep level, RB1, was found to control carrier lifetime together with $\mathrm{Z}_{1 / 2}$ in the other chloride cell $\mathrm{C} 1$. Recombination rate simulations and $p^{+} / n$-junction DLTS showed that RB1 has a minority (hole) capture cross section greater than the majority (electron) capture cross section. The RB1 lifetime killer is formed in the presence of iron contamination under conditions favorable for the growth of samples with low $\mathrm{Z}_{1 / 2}$ concentrations and it is either an intrinsic defect similar to $\mathrm{EH} 5$ or $\mathrm{RD}_{1 / 2}$, or a complex involving iron. Corrosion of reactor 
parts by chlorinated chemistry was found to be the source of the iron contaminant. When these corrosion problems can be controlled however, we find that chlorinated chemistry allows for samples to be produced at significantly higher growth rates than standard chemistry while giving equal or higher minority carrier lifetimes based on $Z_{1 / 2}$ as the sole bulk deep level recombination center.

\section{AUTHOR INFORMATION}

\section{Corresponding Author}

*ianbo@ifm.liu.se

\section{Funding Sources}

The Swedish Energy Agency, Swedish Research Council (VR), Swedish Foundation for Strategic Research (SSF) and LG Innotek are gratefully acknowledged for their support.

\section{ACKNOWLEDGEMENTS}

We thank Henrik Pedersen, Stefano Leone and Ildiko Farkas for some of the sample preparations.

\section{REFERENCES}

[1] Miyake, H.; Okuda, T.; Niwa, H.; Kimoto, T.; Suda, J. IEEE Electron Device Lett. 2012, 33 (11), 1598-1600.

[2] Leone, S.; Beyer, F.C.; Henry, A.; Hemmingsson, C.; Kordina, O.; Janzén, E. Cryst. Growth and Design 2010, 10 (8), 3743-3751.

[3] Klein, P.B. J. Appl. Phys. 2008, 103, 033702. 
[4] Klein, P.B.; Shanabrook, B.V.; Huh, S.W.; Polyakov, A.Y.; Skowronski, M.; Sumakeris, J.J.; O’Loughlin, M.J. Appl. Phys. Lett. 2006, 88, 052110.

[5] Son, N.T.; Trinh, X.T.; Løvlie, L.S.; Svensson, B.G.; Kawahara, K.; Suda, J.; Kimoto, T.; Umeda, T.; Isoya, J.; Makino, T.; Ohshima, T.; Janzén, E. W. Phys. Rev. Lett. 2012, 109, 187603.

[6] Istratov, A.A.; Hieslmair, H.; Weber, E.R. Appl. Phys. A. 2000, 70, 489-534.

[7] Macdonald, D.; Rosenits, P.; Deenapanray, P.N.K. Semicond. Sci. Technol. 2007, 22, 163167.

[8] Beyer, F.C.; Pedersen, H.; Henry, A.; Janzén, E. Mat. Sci. Forum 2009, 615-617, 373-376.

[9] Danno, K.; Hori, T.; Kimoto, T. J. Appl. Phys. 2007, 101 (5), 053709.

[10] Henry, A.; ul Hassan, J.; Bergman, J.P.; Hallin, C.; Janzén, E. Chem. Vap. Deposition 2006, $12,475-482$.

[11] Kordina, O.; Hallin, C.; Henry, A.; Bergman, J.P.; Ivanov, I.; Ellison, A.; Son, N.T.; Janzén, E. phys. Stat. Sol. (b) 1997, 202, 321-334.

[12] Pedersen, H.; Leone, S.; Kordina, O.; Henry, A.; Nishizawa, S.-I.; Koshka, Y.; Janzén, E. Chemical Reviews 2012, 112 (4), 2434-2453.

[13] Leone, S.; Beyer, F.C.; Pedersen, H.; Kordina, O.; Henry, A.; Janzén, E. Cryst. Growth and Design 2010, 10 (12), 5334-5340.

[14] Pedersen, H.; Leone, S.; Henry, A.; Lundskog, A.; Janzén, E. phys. stat. sol. - Rapid Research Lett. 2008, 2 (6), 278-280. 
[15] Istratov, A.A. Rev. Sci. Instrum. 1997, 68 (10), 3861-3865.

[16] Crowell, C.R.; Alipanahi, S. Solid-State Electron. 1981, 24, 25-36.

[17] Patnaik, P. Handbook of inorganic chemicals 2002, McGraw-Hill Companies, Inc. (New York, USA).

[18] Hemmingsson, C.G.; Son, N.T.; Ellison, A.; Zhang, J.; Janzén, E. Phys. Rev. B 1998, 58 (16), 119-122.

[19] Beyer, F.C.; Hemmingsson, C.G.; Leone, S.; Lin, Y.-C.; Gällström, A.; Henry, A.; Janzén, E. J. Appl. Phys. 2011, 110 (12), 123701.

[20] Blood, P.; Orton, J.W. The Electrical Characterization of Semiconductors: Majority Carriers and Electron States 1992, Academic Press (London, UK).

[21] Kimoto, T.; Hiyoshi, T.; Hayashi, T.; Suda, J. J. Appl. Phys. 2010, 108, 083721.

[22] Ayedh, H.M.; Bobal, V.; Nipoti, R.; Hallén, A.; Svensson, B.G. J. Appl. Phys. 2014, 115, 012005.

[23] Hornos, T.; Gali, Á.; Svensson, B.G. Mater. Sci. Forum 2011, 679-680, 261-264.

[24] Kotamraju, S.; Krishnan, B.; Beyer, F.C.; Henry, A.; Kordina, O.; Janzén, E.; Koshka, Y. Mater. Sci. Forum 2012, 717-720, 129-132.

[25] Kato, M.; Tanaka, S.; Ichimura, M.; Arai, E.; Nakamura, S.; Kimoto, T.; Pässler, R. J. Appl. Phys. 2006, 100, 053708. 
[26] Dalibor, T.; Pensl, G.; Matsunami, H.; Kimoto, T.; Choyke, W.J.; Schöner, A.; Nordell, N. phys. stat. sol. (a) 1997, 162, 199.

[27] Hemmingsson, C.; Son, N.T.; Kordina, O.; Bergman, J.P.; Janzén, E.; Lindström, J.L.;

Savage, S.; Nordell, N. J. Appl. Phys. 1997, 81 (9), 6155-6159.

[28] Lebedev, A.A.; Veĭnger, A.I.; Davydov, D.V.; Kozlovskiı̆, V.V.; Savkina, N.S.; Strel'chuk, A.M. Semiconductors 2000, 34 (9), 1016-1020.

[29] Reshanov, S.A.; Beljakowa, S.; Zippelius, B.; Pensl, G.; Danno, K.; Alfieri, G.; Kimoto, T.; Onoda, S.; Ohshima, T.; Yan, Fei; Devaty, R.P.; Choyke, W.J. Mater. Sci. Forum 2010, $645-$ $648,423-426$. 


\section{For Table of Contents Use Only}

\section{Synopsis}

Two lifetime limiting recombination centers, $Z_{1 / 2}$ and the previously unreported $\mathrm{RB} 1$ are found in $4 \mathrm{H}-\mathrm{SiC}$ epilayers grown using chlorinated chemistry. RB1 is linked to iron contamination of the growth cell produced by etching of steel reactor parts by the chlorinated chemistry.

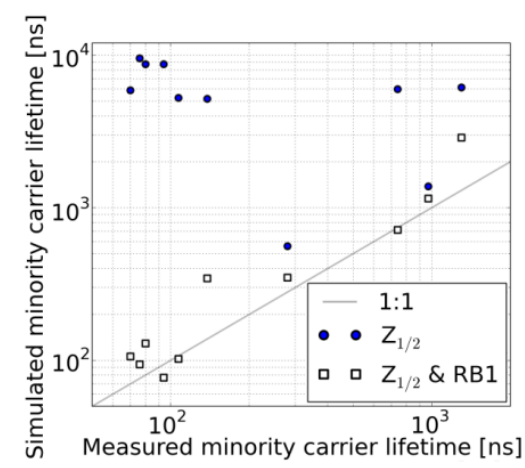

For Table of Contents Only. 